\title{
Penerapan Model Pembelajaran Kooperatif Tipe Student Teams Achievement Division Materi Pengangguran di SLB Negeri Seunagan
}

\author{
Nurhasanah \\ Guru SLB Negeri Seunagan Nagan Raya \\ Email : nurhasanah.slb@gmail.com \\ DOI : 10.32672/jsa.v7i5.1521
}

\begin{abstract}
ABSTRAK
Ekonomi merupakan salah satu mata pelajaran yang diajarkan di tingkat SLB. Dalam mempelajari ekonomi terdapat banyak pendekatan pembelajaran yang bisa digunakan untuk meningkatkan prestasi belajar siswa. Salah satunya ialah pendekatan pembelajaran kooperatif tipe STAD sebagai tindakan yang digunakan untuk mengajar materi pengangguran. Pendekatan penelitian yang digunakan adalah pendekatan kuantitatif. Tujuan penelitian ini adalah untuk mengetahui peningkatan prestasi belajar siswa dengan menggunakan pembelajaran kooperatif pada materi pengangguran melalui tipe STAD sesuai dengan langkah-langkah yang telah ditetapkan. Penelitian ini adalah penelitian tindakan kelas (PTK) yang dilaksanakan di SLB Negeri Seunagan Nagan Raya. Adapun yang menjadi subjek penelitian adalah seluruh siswa kelas VIII SLB Negeri Seunagan Nagan Raya yang berjumlah 23 orang siswa. Data diperoleh dari tes hasil belajar siswa dan lembaran pengamatan aktivitas guru dan siswa terhadap pendekatan pembelajaran berbasis masalah. Data ini dianalisis dengan menggunakan rumus persentase. Nilai siswa terus meningkat dari RPP-1 dan RPP-2. Pada tes akhir diperoleh persentase siswa yang memenuhi kriteria tinggi mencapai $34,78 \%$ sedang sebesar $69,59 \%$, dan memenuhi kriteria rendah sebesar $0 \%$. Jadi terdapat peningkatan dalam pembelajaran siswa pada materi pengangguran dengan menggunakan model pembelajaran kooperatif tipe STAD. Aktivitas guru yang paling dominan dilakukan adalah mempresentasikan materi serta memberi latihan mandiri. Aktivitas siswa yang paling dominan adalah mendengar, memperhatikan penjelasan guru serta dapat memperhatikan penjelasan teman dalam kelompok serta dapat mempresentasikan kembali kepada teman kelompok dan dapat menjawab pertanyaan. Sehingga dengan melakukan pembelajaran model kooperatif tipe STAD dapat meningkatkan prestasi belajar siswa pada materi pengangguran. Kata kunci: Hasil Belajar, Pengangguran, Ekonomi, STAD
\end{abstract}

\section{PENDAHULUAN}

Salah satu permasalahan yang dihadapi dunia pendidikan kita adalah rendahnya kualitas hasil belajar dan proses belajar yang dicapai siswa. Rendahnya kualitas hasil belajar disebabkan oleh penggunaan model belajar yang belum tepat dimana model yang digunakan adalah guru aktif dan siswa pasif missal model ceramah. Dalam pembelajaran yang demikian sangat membosankan bagi siswa dan prestasi belajar pun menurun, karena 
Nurhasanah

siswa tidak dilibatkan dalam kreatifitas yang tinggi. Dalam meningkatkan mutu pendidikan salah satunya adalah dengan menerapkan model pembelajaran yang tepat sesuai dengan materi yang diajarkan serta diterapkan dalam proses belajar khususnya mata pelajaran ekonomi. Pembelajaran ekonomi tidak lagi mengutamakan pada penyerapan melalui pencapaian informasi, tetapi lebih mengutamakan pada pengembangan kemampuan dan pemrosesan informasi. Untuk itu aktivitas peserta didik perlu ditingkatkan melalui latihan-latihan atau tugas ekonomi dengan bekerja kelompok kecil dan menjelaskan ide-ide kepada orang lain. Dalam komunikasi tersebut diharapkan siswa dapat menguasai materi pelajaran dengan mudah karena siswa lebih mudah memahami penjelasan dari kawannya dibanding penjelasan dari guru karena taraf pengetahuan serta pemikiran mereka lebih sejalan dan sepadan (Wahyuni, 2001:2).

Prestasi merupakan kumpulan hasil akhir dari suatu yang pekerjaan yang telah dilakukan. Prestasi tidak datang begitu saja, untuk mendapatkannya harus melalui perjuangan yang keras. Asmara (2009:11) Asmara mengemukakan pengertian prestasi belajar adalah suatu bentuk pencapaian atas usaha seseorang dalam penguasaan materi, keterampilan, maupun pengetahuan yang ditunjukkan ataupun diwakilkan dalam bentuk nilai. Pendapat lainnya menyatakan prestasi adalah hasil yang dicapai, dilakukan, dikerjakan (Poerwadarminto, 2003:910). Dari pendapat di atas dapat ditarik kesimpulan bahwa prestasi merupakan hasil usaha yang dicapai seseorang yang terlebih dahulu melakukan kegiatan. Belajar merupakan suatu proses panjang dari lahir hingga akhir hayat. Belajar dapat diperoleh melalui pendidikan formal maupun nonformal yaitu pendidikan dari keluarga dan lingkungannya sampai pendidikan sekolah yang mempunyai tujuan untuk merubah tingkah laku, sikap, keterampilan, kebiasaan serta perubahan seseorang kearah yang lebih baik.

Adanya anggapan bahwa materi pelajaran ekonomi tidak dapat mengembangkan kemampuan berpikir memecahkan persoalan dengan menggunakan potensi otak. Akibatnya proses pembelajaran adalah mendengar, mencatat dan menghafal sesuai sumber belajar yang ditentukan. Asumsi inilah yang kemudian mendorong siswa untuk menempatkan pelajaran ekonomi sebagai mata pelajaran yang membosankan sebagian siswa. Sehingga diperlukan model pembelajaran yang dapat mengatasi permasalahn ini yaitu dengan model pembelajaran kooperatif tipe Student Teams Achievement Division (STAD). Model diartikan sebagai cara melakukan suatu kegiatan atau cara melakukan pekerjaaan dengan menggunakan fakta dan konsep-konsep secara sistematis (Syah, 2004:201). Dalam dunia psikologi model berarti prosedur sistematis (tata cara yang berurutan) yang biasa digunakan unuk menyelidiki fenomena (gejala-gejala) kejiwaan seperti model klinik, dan sebagainya. Menurut Slavin (Rusman, 2012:213), model STAD (Student Team Achievement Division) merupakan variasi pembelajaran kooperatif yang paling banyak diteliti. Pendapat lain dari Trianto (2009: 68) mengemukakan pembelajaran kooperatif tipe STAD adalah model pembelajaran kooperatif dengan menggunakan kelompok-kelompok kecil dengan jumlah anggota tiap kelompok 4-5 siswa secara heterogen, yang merupakan campuran menurut tingkat prestasi, jenis kelamin, dan suku. Diawali dengan penyampaian tujuan pembelajaran, penyampaian materi, kegiatan kelompok, kuis, dan penghargaan kelompok. 
Pembelajaran kooperatif mempunyai unsur-unsur yang perlu diperhatikan. Unsurunsur tersebut sebagai berikut: 1) Para siswa harus kooperatif harus memiliki persepsi bahwa mereka "tenggelam atau berenang bersama"; 2) Para siswa memiliki tanggungjawab terhadap siswa yang laindalam kelompoknya, disamping tanggungjawab terhadap dirinya sendiri, dalam mempelajari materi yang dihadapi; 3) Para siswa harus berpandangan bahwa mereka semuanya memiliki tujuan yang sama; 4) Para siswa harus membagi tugas dan berbagai tanggung jawab samabesarnya diantara para anggota kelompok; 5) Para siswa akan diberikan satu evaluasi atau penghargaan yang akan ikut berpengaruh terhadap evaluasi seluruh anggota kelompok; 6) Para siswa berbagi kepemimpinan sementara mereka memperoleh keterampilan bekerjasama selama belajar; 7) Para siswa akan diminta mempertanggungjawabkan secara individual materi yang ditangani dalam kelompok kooperatif.

Berdasarkan fenomena diatas, maka penulis tertarik untuk melakukan penelitian kelas dengan judul Optimalisasi Penerapan Model Pembelajaran Kooperatif Tipe STAD Materi Pengangguran Kelas VIII Semester Genap SLB Negeri Seunagan Nagan Raya.

\section{METODE PENELITIAN}

Penelitian ini di lakukan selama 3 bulan di SLB Negeri Seunagan Nagan Raya. Subjek dalam penelitian ini adalah siswa kelas VIII SLB Negeri Seunagan Nagan Raya yang berjumlah 23 siswa. Prosedur penelitian yang ditetapkan dalam penelitian ini adalah Penelitian Tindakan Kelas (PTK) yang terdiri dari tahap perencanaan, tindakan (action), observasi dan refleksi yang dilaksanakan dalam dua siklus. Data dalam penelitian ini diperoleh dari hasil belajar siswa dan dari lembar observasi. Analisis data untuk hasil belajar siswa dianalisis secara deskriptif yaitu mencari rata-rata, persentase yang mencapai KKM. Sedangkan untuk hasil observasi dianalisis menggunakan persentase.

\section{HASIL PENELITIAN DAN PEMBAHASAN Pelaksanaan Pra siklus}

Dalam pelaksanaan pembelajaran materi pengangguran dibagi menjadi 2 siklus pada tiap-tiap siklus di lengkapi dengan masing-masing RPP yaitu RPP I dan RPP II. Untuk mendapatkan hasil pengamatan terhadap aktifitas guru dan siswa menggunakan penerapan model pembelajaran kooperatif dilakukan oleh 2 orang pengamat. Setiap pengamat mengamati kegiatan belajar mengajar yang berlangsung.

\section{Proses Pelaksaaan Pembelajaran Kooperatif Tipe STAD}

Langkah-langkah dalam penyajian materi pengangguran adalah sebagai berikut :

1. Guru mengkelompokan siswa dengan masing-masing kelompok yang terdirii dari 3 sampai dengan 5 orang. Anggota-anggota kelompok di buat heterogen meliputi karakteristik kecerdasan, kemampuan-kemampuan awal Bahasa Indonesia, motivasi belajar, jenis kelamin serta latar belakang etnis yang berbeda. 
Nurhasanah

2. Kegiatan pembelajaran di mulai dengan presentasi guru dalam menjelaskan pelajaran berupa paparan masalah pemberian data dan pemberian contoh. Tujuan presentasi adalah untuk mengenalkan konsep dan mendorong rasa ingin tahu siswa.

3. Pemberian tugas pada kelompok, mereka boleh mengerjakan tugas-tugas tersebut secara serentak atau saling bergantian menanyakan kepada temannya sampai semuanya memahami materi pelajaran tersebut.

4. Guru memberi tes atau kuis individual dan teman sekelompoknya tidak boleh menolong satu sama lainya.

5. Guru membandingkan hasil tes kuis dengan rata-rata sebelumnya dan poin akan diberikan berdasarkan tingkat keberhasilan siswa mencapai atau melebihi kinerja sebelumnya. Poin di jumlahkan untuk membentuk skor kelompok.

6. Guru memberi penghargaan pada kelompok yang terbaik yang telah memenuhi kriteria tertentu berupa hadiah atau sertifikat.

Kegiatan inti terdiri dari:

1. Fase I menyampai tujuan pembelajaran dan motivasi siswa.

2. Fase II menyajikan informasi tentang pengangguran.

3. Fase III mengorganisasikan siswa keadaan kelompok-kelompok belajar.

4. Fase IV membimbing siswa bekerja dan belajar untuk kepentingan kelompok.

5. Fase V evaluasi.

Penutup.

1. Membimbing siswa untuk merangkum materi pelajaran

2. Memberi pekerjaan rumah dengan menyelesaikan soal-soal latihan yang ada pada buku paket

\section{Hasil Pengamatan Aktifitas Guru dan Siswa Dalam Penerapan Pembelajaran Kooperatif}

Pengamatan terhadap aktifitas guru dan siswa selama kegiatan belajar mengajar berlangsung di nyatakan dengan rumus persentase. Adapun aktifitas guru dan siswa selama pembelajaran berlangsung dalam setiap rencana pembelajaran disajikan dalam tabel 1 dan tabel 2 berikut.

Tabel 1. Aktifitas Guru Dan Siswa Selama Proses Pembelajaran Tiap-tiap RPP

\begin{tabular}{|c|l|c|c|c|}
\hline No & \multicolumn{1}{|c|}{ Aktifitas Guru } & $\begin{array}{c}\text { RPP-1 } \\
\%\end{array}$ & $\begin{array}{c}\text { RPP-2 } \\
\%\end{array}$ & $\begin{array}{c}\text { Rata-rata } \\
\%\end{array}$ \\
\hline$(1)$ & \multicolumn{1}{|c|}{$(2)$} & $(3)$ & $(4)$ & $(5)$ \\
\hline 1 & Menyampaikan tujuan & 5,20 & 7,53 & 6,37 \\
\hline 2 & Menjelaskan materi & 17,23 & 18,10 & 17,76 \\
\hline 3 & Mendemonstrasikan materi dengan benar & 10,12 & 10,78 & 10,45 \\
\hline 4 & Memberikan latihan terbimbing & 10,75 & 10,97 & 10,86 \\
\hline 5 & Memeriksa pemahaman dan umpan balik & 9,07 & 12,31 & 10,69 \\
\hline 6 & Memberikan latihan mandiri & 13,41 & 15,85 & 14,63 \\
\hline 7 & Mengamati kegiatan siswa & 14,19 & 14,63 & 14,41 \\
\hline 8 & $\begin{array}{l}\text { Membimbing siswa menyimpulkan } \\
\text { pembelajaran }\end{array}$ & 12,19 & 18,29 & 15,24 \\
\hline
\end{tabular}


Berdasarkan hasil pengolahan data pada tabel di atas dapat kita lihat bahwa aktifitas guru dalam menerapkan model pembelajaran kooperatif rata-rata persentase yang dominan dilakukan guru adalah menjelaskan materi sebesar $(17,67)$ dan memberi latihan mandiri sebanyak $(14,63)$.

Hal ini sesuai dengan menggunakan model pembelajaran kooperatif di tuntut guru untuk mempresentasikan, menugaskan serta membandingkan hasil tes kuis dengan ratarata sebelumnya sekaligus memberikan penghargaan berupa hadiah dan sebagainya, sesuai dengan teori penerapan pembelajaran kooperatif tipe STAD adalah pembelajaran yang berbasis konstruktifisme menekankan pada siswa membangun sendiri pengetahuan mereka lewat keterlibatan aktif dalam proses belajar-mengajar. Proses belajar-mengajar lebih berorientasi pada siswa (student centered), di bandingkan dengan kegiatan yang berpusat pada guru (teacher centered).

Sumber belajar bagi siswa bukan hanya guru dan buku ajar tetapi juga dari sesame siswa.Belajar kooperatif besar sekali menafaatnya untuk pembentukan kepribadian siswa saling mengasihi, saling menghargai, dan saling memberi dukungan antar sesama siswa (silih asah, silih asih, dan silih asuh).

Tabel 2. Aktifitas Siswa Selama Proses Belajar-Mengajar Tiap-tiap RPP

\begin{tabular}{|c|l|c|c|c|}
\hline \multirow{2}{*}{ No } & \multicolumn{1}{|c|}{ Aktifitas Guru } & $\begin{array}{c}\text { RPP-1 } \\
\%\end{array}$ & $\begin{array}{c}\text { RPP-2 } \\
\%\end{array}$ & $\begin{array}{c}\text { Rata-rata } \\
\%\end{array}$ \\
\hline$(1)$ & \multicolumn{1}{|c|}{$(2)$} & $(3)$ & $(4)$ & $(5)$ \\
\hline 1 & Mendengarkan/memperhatikan penjelasan guru & 17,20 & 23,02 & 20,11 \\
\hline 2 & Menulis pelajaran yang relevan dengan KBM & 15,20 & 12,78 & 13,99 \\
\hline 3 & Mengajukan pertanyaan & 11,83 & 12,25 & 12,04 \\
\hline 4 & Membaca buku & 20,60 & 13,21 & 16,91 \\
\hline 5 & Berdiskusi/bertanya antara guru dan siswa & 17,76 & 16,10 & 16,93 \\
\hline 6 & Menyampaikan pendapat & 12,75 & 15,60 & 14,18 \\
\hline 7 & Menyimpulkan materi & 9,60 & 12,65 & 11,13 \\
\hline
\end{tabular}

Sumber :Data primer (diolah, 2016)

Berdasarkan hasil pengamatan data pada tabel di atas dapat kita lihat bahwa aktifitas siswa yang paling dominan dilakukan siswa selama KBM berlangsung untuk semua RPP adalah mendengarkan/memperhatikan penjelasan guru sebesar $(20,11 \%)$ bertanya antara guru dengan siswa sebesar $(16,93 \%)$ membaca buku sebesar $(16,91 \%)$ dan seterusnya. Anggota kelompok bertanggung jawab atas ketuntasan tugas-tugas kelompok dan untuk mempelajari materi itu sendiri.

\section{Hasil Tes Belajar Siswa}

Hasil tes ini diolah dengan menggunakan rumus persentase.Datanya di peroleh dari hasil tes yang diberikan kepada siswa setiap kali awal dan terakhir. Secara ringkas dapat kita lihat pada tabel 3 di bawah ini. 
Nurhasanah

Tabel 3. Daftar Nilai Siswa Kelas VIII-2 selama KBM

\begin{tabular}{|c|l|c|c|c|}
\hline NO & \multicolumn{1}{|c|}{ NAMA } & RPP-1 & RPP-2 & TES AKHIR \\
\hline 1 & Agung Prasetya & 50 & 55 & 65 \\
\hline 2 & Afifah Irnanda & 80 & 90 & 95 \\
\hline 3 & Abdurrun Nafis & 60 & 65 & 80 \\
\hline 4 & Akhyar Tri Haryatna & 80 & 80 & 90 \\
\hline 5 & Ajir Azhar & 40 & 50 & 65 \\
\hline 6 & Ananda Furqan & 45 & 50 & 60 \\
\hline 7 & Bustanul Aulia & 65 & 70 & 80 \\
\hline 8 & Cut Haliza & 50 & 55 & 65 \\
\hline 9 & Farah Zanuba & 55 & 65 & 70 \\
\hline 10 & Firza Maulana & 60 & 70 & 80 \\
\hline 11 & Fadilah Fasya & 50 & 65 & 70 \\
\hline 12 & Khaira Yuhafiza & 50 & 65 & 70 \\
\hline 13 & Lia Agustin & 45 & 60 & 65 \\
\hline 14 & Mursalin & 60 & 65 & 70 \\
\hline 15 & Maulita Sartina & 65 & 70 & 80 \\
\hline 16 & Mutia Apriani & 65 & 65 & 70 \\
\hline 17 & Maranti Wulandari & 65 & 70 & 70 \\
\hline 18 & Mahdafi Sahar & 60 & 70 & 75 \\
\hline 19 & Muhammad Arifin & 50 & 60 & 65 \\
\hline 20 & Nurfita nadila & 70 & 80 & 85 \\
\hline 21 & Fadhli & 60 & 75 & 85 \\
\hline 22 & Sinta Marbela & 50 & 65 & 70 \\
\hline 23 & Tariqul Riski Akbar & & \\
\hline 5496 & & 65 & \\
\hline
\end{tabular}

Sumber : Data (diolah) 2016

Berdasarkan tabel di atas dapat kita lihat bahwa dengan menggunakan model pembelajaran kooperatif langsung dapat meningkatkan prestasi belajar siswa. Hal ini dikarenakan siswa benar-benar mempelajari dan bekerja sama delam kelompoknya serta mengulanginya kemballi dirumah. Hasil tes yang di capai siswa pada siklus I sampai siklus akhir tersebut disajikan dalam tabel berdasarkan KKM. Adapun hasil disajikan pada tabel di bawah ini

Tabel 4. Distribusi Frekuensi Kemampuan Siswa Dalam Pembelajaran Pada Pokok Bahasan Pengangguran RPP-1

\begin{tabular}{|c|c|c|c|}
\hline Nilai & Kriteria & Frekuensi & Persentase \% \\
\hline $80-100$ & Tinggi & 2 & 8,69 \\
\hline $60-79$ & Sedang & 10 & 43,48 \\
\hline $40-59$ & Rendah & 11 & 47,82 \\
\hline \multicolumn{2}{|c|}{ TOTAL } & 23 & 99,99 \\
\hline
\end{tabular}

Sumber : Data (diolah) 2016 
Tabel 5. Distribusi Frekuensi Kemampuan Siswa Dalam Pembelajaran Pada Pokok Bahasan Pengangguran RPP-2

\begin{tabular}{|c|c|c|c|}
\hline Nilai & Kriteria & Frekuensi & Persentase \% \\
\hline $80-100$ & Tinggi & 3 & 13,04 \\
\hline $60-79$ & Sedang & 16 & 69,59 \\
\hline $40-59$ & Rendah & 4 & 17,39 \\
\hline \multicolumn{2}{|c|}{ TOTAL } & 23 & 99,99 \\
\hline
\end{tabular}

Sumber : Data (diolah) 2016

Tabel 6. Distribusi Frekuensi Kemampuan Siswa Dalam Pembelajaran Pada Pokok Bahasan Pengangguran Pada Tes Akhir

\begin{tabular}{|c|c|c|c|}
\hline Nilai & Kriteria & Frekuensi & Persentase \% \\
\hline $80-100$ & Tinggi & 8 & 34,78 \\
\hline $60-79$ & Sedang & 16 & 69,59 \\
\hline $40-59$ & Rendah & 0 & 0 \\
\hline \multicolumn{2}{|c|}{ TOTAL } & 23 & 99,99 \\
\hline
\end{tabular}

Sumber : Data (diolah) 2016

Berdasarkan hasil pengolahan data yang dikumpulkan dari tes akhir hasil belajar siswa ternyata prestasi belajar pada siklus I masih banyak yang belum menguasai materi pengangguran.Hal ini terbukti bahwa nilai siswa masih sangat rendah, kemudian setelah diajarkan model pembelajaran kooperatif ternyata prestasi belajar siswa sudah meningkat. Maka dengan menggunakan model pembelejaran kooperatif sangat memberikan keuntungan bagi siswa salam proses belajar mengajar, hal ini terbukti dari peningkatan restasi belajar siswa setelah diterapkan model pembelajaran kooperatif pada materi pengangguran.

\section{Pembahasan}

Berdasarkan hasil penelitian yang penulis lakukan adalah penelitian tindakan kelas yang dilakukan dalam menerapkan model pembelajaran kooperatif dapat menuntaskan dan meningkatkan prestasi belajar siswa.

\section{Proses Pembelajaran Kooperatif}

Berdasarkan hasil pengolahan data diatas maka aktifitas guru dan siswa menunjukkan bahwa pembelajaran dengan menggunakan model pembelajaran kooperatif lebih berpusat kepada siswa. Pembelajaran kooperatif adalah suatu pendekatan mengajar yang dapat membantu siswa dalam membentuk proses belajar sesame siswa, untuk melihat hasil pengolahan data tentang aktifitas guru dan siswa melalui model pembelajaran kooperatif pada pokok bahasan pengangguran dapat dilihat pada tabel 2 dan tabel 3 .

\section{Ketuntasan Belajar Dengan Menggunakan Model Pembelajaran Kooperatif}

Tes hasil belajar bertujuan untuk mengetahui sejauh mana tingkat belajar siswa, hasil belajar siswa diperoleh pada pembelajaran dengan menggunakan model 
Nurhasanah

pembelajaran kooperatif. Adapun data nilai yang diperoleh pada tiap-tiap RPP dianalisis dengan menggunakan rumus persentase, dimana penilaian ini bertujuan untuk melihat tuntas atau tidaknya pembelajaran materi pengangguran dengan menggunakan model pembelajaran kooperatif, pada penilaian RPP-1 dengan kriteria tinggi 8,69\%, sedang $43,48 \% \%$, dan rendah $47,82 \%$ pada RPP-2 dengan kriteria tinggi $13,04 \%$, sedang $69,56 \%$ dan rendah $17,39 \%$ kemudian pada tes akhir nilai siswa nilai siswa dalam menguasai konsep pengangguran dengan kriteria tinggi 34,78\%, sedang $69,56 \%$ dan rendah $0 \%$ dengan demikian dapat dikatakan bahwa penggunaan model pembelajaran kooperatif dapat meningkatkan prestasi belajar siswa. Dengan pengingkatan hasil belajar tersebut maka pembelajaran dengan menggunakan model pembelajaran kooperatif tipe STAD dapat dikatakan tuntas.

\section{PENUTUP}

Simpulan

Kegiatan pembelajaran dengan menggunakan model pembelajaran kooperatif dapat meningkatkan prestasi belajar siswa pada materi pengangguran Aktifitas guru dan siswa dengan menggunakan model pembelajaran kooperatif padda materi pengangguran telah dilakukan sesuai dengan langkah-langkah pembelajaran. Aktifitas guru yang paling dominan dilakukan adalah mempresentasikan materi sebesar $17,67 \%$ dan aktifitas siswa yang paling dominan dilakukan adalah mendengarkan/memperhatikan penjelasan guru sebesar $20,11 \%$.

\section{DAFTAR PUSTAKA}

Asmara.2009. Prestasi Belajar.Bandung.PT. Remaja Rosdakarya.

Purwadarminto, WJS. 2003. Kamus Umum Bahasa Indonesia. Jakarta: BalaiPustaka.

Rusman. 2012. Model-model Pembelajaran: Mengembangkan Profesionalisme Guru. Jakarta: PT. Raja Grafindo Persada.

Syah, Muhibbin. 2004. Psikologi Pendidikan. Bandung : Rosda Karya.

Trianto. 2009. Mendesain Model Pembelajaran Inovatif Progresif. Surabaya: Kencana.

Wahyuni, Dwi. 2001. Studi Tentang Pembelajaran Kooperatif Terhadap Hasil Belajar Mengajar. Program Sarjana Universitas Negeri Malang. 